\title{
Factors Affecting Bovine Ketosis and its Association with Non-Return Rate
}

\author{
U. B. LINDSTRÖM ${ }^{1)}$, MARCUS VON BONSDORFF' ${ }^{2)}$ and JOUKO SYVÄJÄRVI ${ }^{3)}$ \\ 1) Department of Animal Breeding, University of Helsinki, 00710 Helsinki 71 \\ 2) East \& Central Finland AI Society, 76620 Pyhitty \\ 3) Finnish Animal Breeding Society, Box 40, 01301 Vantaa 30
}

\begin{abstract}
Data on 16406 cows (6 025 recorded) from the area of the East \& Central AI Society were analysed by least squares procedures. Ketosis incidence was determined from the milk by a commercial keto test reagent by AI technicians in connection with the ordinary first insemination of a particular cow. Ketosis incidence was on average $11.5 \%$, increased up to about the 4 th -5 th parity and was significantly higher in larger herds. Breed did not significantly affect ketosis incidence. There was a tendency for higher incidence with increasing usage of commercial feed mixtures. Cows with ketosis milked less than unaffected ones and cows inseminated earlier than 60 days after calving had significantly higher incidence than cows inseminated later.

The complete statistical models accounted for only $5 \%$ (all herds) and $9 \%$ (recorded herds) of variation in ketosis incidence, indicating the need for better measures of the herd environment. Heritabilities for ketosis incidence were not significantly different from zero.

Cows with ketosis had significantly poorer non-return rates than unaffected ones, indicating the need for prophylactic measures.
\end{abstract}

\section{Introduction}

According to the official veterinary statistics the incidence of ketosis in dairy cattle in Finland is $8 \%$ (ANON. 1980). The first preliminary reports from the recently started health recording system, including data from some 1000 herds, gives the ketosis incidence as $7.9 \%$. A field study by KAUPPINEN (1984) reports a clearly higher figure of $13.1 \%$ of clinically recorded ketosis cases. Ketosis is thus one of the major cattle diseases, second only to mastitis in our country.

Between 1969 and 1979 the non-return-(NR) rates in the area of the East \& Central Finland AI Society has steadily dropped, especially in the indoor feeding period, between January and May (see Fig. 1). It has also, in accordance with the literature (see e.g. EKESBO 1966, ERB \& MARTIN 1978, PEHRSON 1966 and SOLBU 1983), been observed that the incidence of ketosis 


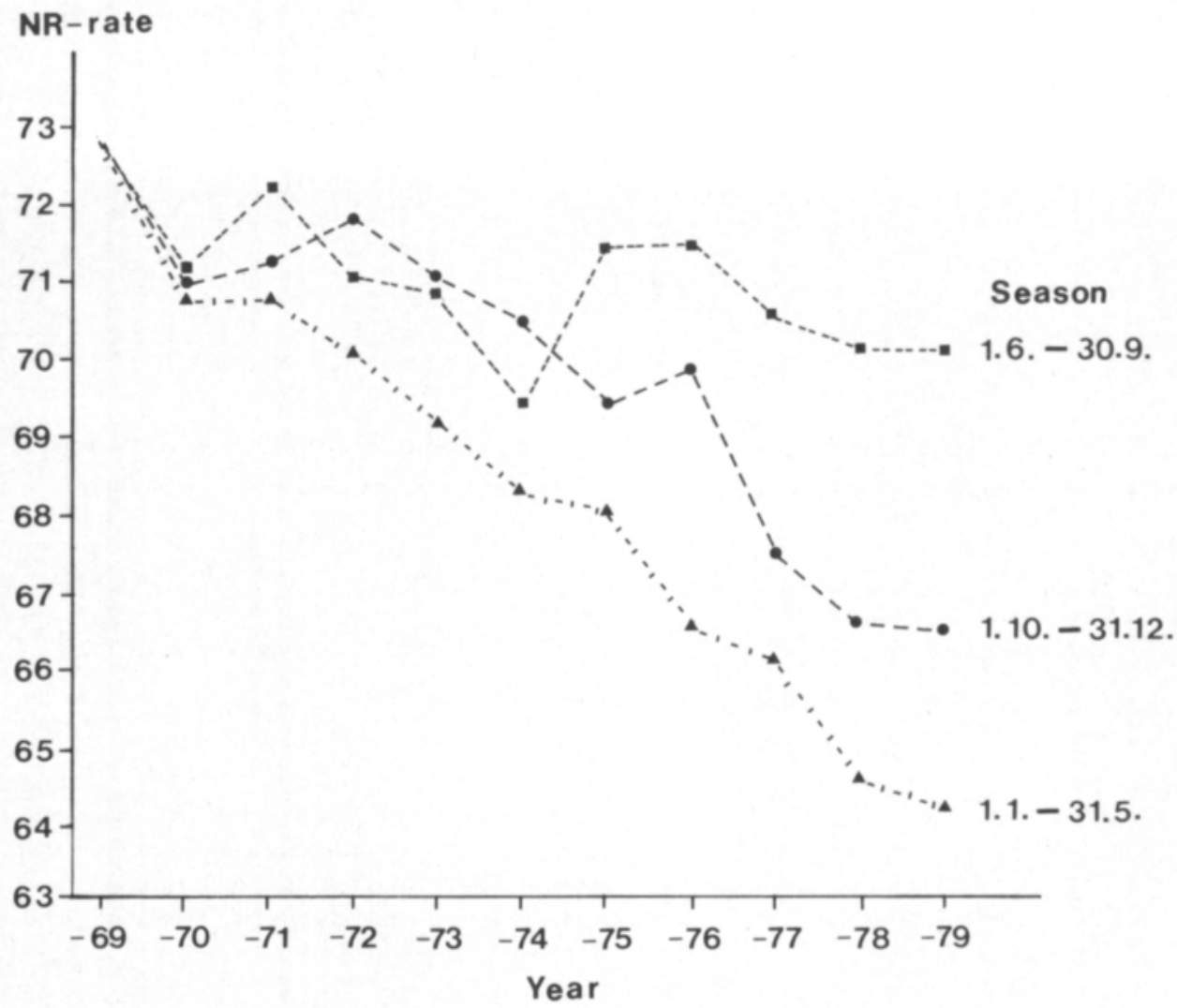

Figure 1. Development of the 60-day non-return (NR)-rate in the area of the East \& Central Finland AI Society in the period 1969-1979. (The data consists of some 200000 first insemination per year, pooled for all breeds).

is highest in early spring, in March - May, which coincides with the lowest values noted for the NR-rate.

It is well known that a number of systematic and random factors, e.g. parity, milk yield, feeding system, affect the incidence of ketosis; for a topical review reference is made to SOLBU (1983).

The main purposes of the present study were:

1) To check the usefulness of a commercially available "Keto-test reagent".

2) To investigate the influence of various factors on the incidence of bovine ketosis under field conditions.

3) To examine the effect of ketosis on the NR-rates.

\section{Material and methods}

\section{Data collection}

The material consists of data on a total of 16406 cows, of which 6025 (41 $\%$ ) were in recorded herds. Of all cows $52 \%$ were ayrshire (ay), $20 \%$ 
finncattle (fc) and $28 \%$ friesian (fr). On average, the herd size was 10.4 cows, the cows had calved 3.3 times, and the daily milk yield was $24 \mathrm{~kg}$.

The material was collected in April and May 1980 in the area of the East \& Central Finland AI Society by the AI technicians. In connection with the ordinary visits to the farms the technicians collected a milk sample (from one teat) of each cow that was due for first insemination after calving. Because of the small herd size only one cow from each herd generally got included in the material.

Immendiately after collection a few drops of milk were put on the "Keto test reagent" (Lääke Oy preparation) and the change in colour was judged on the following subjective scale:

Score 1 - normal milk, no change, $<0.05 \%$ ketone bodies

Score 2 - noticeable change in colour, $0.1-0.2 \%$ ketone bodies

Score 3 - very strong change in colour, $0.5-1.0 \%$ ketone bodies

During the farm visits the technicians also collected information on the feeding systems practised. The herds were grouped into one of four major feeding systems:

1) Concentrate feeds grown on farm + hay

2) Concentrate feeds grown on farm + hay + silage

3) Grain preserved by acid + hay + silage

4) Commercial concentrate mixture + hay + silage

Of these the two first ones most clearly represent feeding regimes based on the farm's own fodder production, the last one a regime depending heavily on commercially available concentrate mixtures and no 3 is in between. The above grouping is, naturally, only indicative as it is based on the farmers own evaluations.

For each cow the farmers were asked about treatment for ketosis. The treatment was originally scored as $1=$ not treated, $2=$ treated by farmer and 3 = treated by veterinarian, but in the statistical analyses 2 and 3 were combined to one group.

Other relevant data for the herds and cows were mainly obtained from the files of the Agricultural Computing Centre, for the non-recorded herds supplemented with information provided by the farmer. For the nonrecorded herds no exact information was available on milk yields and days of calving. For the recorded cows the daily milk yield utilised in this study is the production on the recording day closest to the sampling event.

\section{Statistical analyses}

The various effects were tested by least squares procedures for data with unequal subclass number using the Statistical Analysis System (SAS 1979). Ketosis incidence for the recorded cows was analysed by the following model:

$\mathrm{Y}_{\mathrm{i} \mid \mathrm{kmnoqr}}=\mu+\mathrm{a}_{\mathrm{i}}+\mathrm{b}_{\mathrm{i}}+\mathrm{c}_{\mathrm{k}}+\mathrm{f}_{\mathrm{m}}+\mathrm{g}_{\mathrm{n}}+\mathrm{h}_{\mathrm{o}}+\mathrm{p}_{\mathrm{q}}+\mathrm{e}_{\mathrm{ijklmnoqr}}$ 
where $\mu=$ theoretical mean when equal subclass numbers exist

$\mathrm{a}_{\mathrm{i}}=$ effect $\mathrm{i}^{\text {th }}$ herd size, $\mathrm{i}=1 \ldots 4$

$b_{j}=$ effect of $j^{\text {th }}$ breed, $j=1 \ldots 3$

$c_{k}=$ effect of $k^{\text {th }}$ parity group, $k=1 \ldots 6$

$\mathrm{f}_{\mathrm{m}}=$ effect of $\mathrm{m}^{\text {th }}$ feeding system, $\mathrm{m}=1 \ldots 4$

$\mathrm{g}_{\mathrm{n}}=$ effect of $\mathrm{n}^{\text {th }}$ days of calving group, $\mathrm{n}=1 \ldots 6$

$\mathrm{h}_{\mathrm{o}}=$ effect of $\mathrm{o}^{\text {th }}$ treatment group, $\mathrm{o}=1,2$

$\mathrm{P}_{\mathrm{q}}=$ effect of $\mathrm{q}^{\text {th }}$ daily milk yield class, $\mathrm{q}=1 \ldots 5$

$\mathrm{e}_{\mathrm{i} i \mathrm{kmnogr}}=$ random errors assumed to be $\operatorname{NID}\left(0, \sigma_{\mathrm{e}}^{2}\right)$.

All other effects are considered fixed.

Data for all cows (recorded and non-recorded) were analysed by a model excluding the $\mathrm{g}_{\mathrm{n}}$ - and $\mathrm{p}_{\mathrm{q}}$-effects and including a $\mathrm{d}_{\mathrm{l}}$-effect of the recording class $(1=1,2)$. In analysing the data on NR-rate the above models were used, replacing the $\mathrm{h}_{\mathrm{o}}$-effect with the ketosis score.

In addition, an attempt was made to estimate the heritability of the ketosis score by including in the above model(s) a random sire effect, including the 250 sires with the largest numbers of daughters.

It must be stressed that ketosis, as registered in this study, is for all practical purposes distributed as a binomial character, and thus there is a connection between the mean and the variance. This will affect all statistical tests, more so the lower the disease incidence is. In the present study the ketosis incidence is well over $10 \%$ and thus the significance tests should not be severely biased.

\section{Results and discussion}

\section{Ketosis, general}

On an average, the ketosis incidence (score 2 and 3$)$ was $11.5 \%(13.3 \%$ in recorded herds). This is dearly higher than in the official veterinary statistics and the preliminary results from the health recording, but in close agreement with the study by KAUPPINEN (1984) and Norwegian results (SOLBU 1983). One possible reason for the difference in incidence between the Finnish studies may be that in both Kauppinen's and our study the sampling was restricted to the indoor feeding period, when the problem is most pronounced. Moreover, it is probable that a study including also treatments done by the farmers themselves will give a higher incidence than one inadequately registering these.

Table 1 gives the ANOVA for the effects of the studied factors. Breed and recording class were not statistically significant, all other effects were highly significant. However, the models used accounted for only about $5 \%$ (all herds) and $9 \%$ (recorded herds) of the variation in ketosis incidence as judged from the $\mathrm{R}^{2}$-values. This is in good agreement with the recent study by SOLBU (1983). Apparently the usefulness of various fixed factors, associated with the herd and/or the cow, is relatively small. 
Table 1. LS-analysis of variance of various fixed factors affecting incidence of ketosis in recorded (R) and all (A) herds.

\begin{tabular}{|c|c|c|c|c|c|c|}
\hline \multirow{3}{*}{$\begin{array}{l}\text { Source of } \\
\text { variation }\end{array}$} & \multicolumn{2}{|c|}{ Df } & \multicolumn{2}{|c|}{ Sum of squares } & \multicolumn{2}{|c|}{$\mathrm{F}$} \\
\hline & A & $\mathrm{R}$ & A & R & A & $\mathrm{R}$ \\
\hline & & & $\mu=1.127 \pm 0.013$ & $\mu=1.145 \pm 0.028$ & & \\
\hline Total & 16406 & 6025 & 2237.202 & 925.216 & & \\
\hline Herd size & 3 & 3 & 6.121 & 2.176 & $15.7^{\text {\#\#\# }}$ & $5.2^{\text {th+1 }}$ \\
\hline Breed & 2 & 2 & 0.314 & 0.502 & $1.2^{\mathrm{ns}}$ & $1.8^{\mathrm{ns}}$ \\
\hline Parity & 5 & 5 & 4.248 & 3.973 & $6.5^{\text {\#\#\# }}$ & $4.7^{\text {क\#\# }}$ \\
\hline Record. or not & 1 & - & 0.057 & - & $0.4^{\mathrm{ns}}$ & - \\
\hline Feeding system & 3 & 3 & 5.158 & 0.818 & 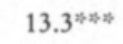 & $1.9^{\mathrm{ns}}$ \\
\hline Days from calving & - & 5 & - & 20.859 & - & $29.7^{m+n}$ \\
\hline Treatment or not & 1 & 1 & 7.347 & 39.668 & 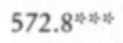 & $140.8^{\text {thnt }}$ \\
\hline Daily milk yield & - & 4 & - & 3.569 & - & $6.3^{\text {thn }}$ \\
\hline Error & 16391 & 5990 & 2127.455 & 844.863 & & \\
\hline
\end{tabular}

- not available $\quad$ ns $=$ not signif.

$$
{ }^{* * *}=\mathrm{P}<0.001
$$

Parity and herd size

From fig. 2 is apparent that the ketosis incidence increases up to about the $4^{\text {th }}-5^{\text {th }}$ parity and then levels out. This is in agreement with the literature (see
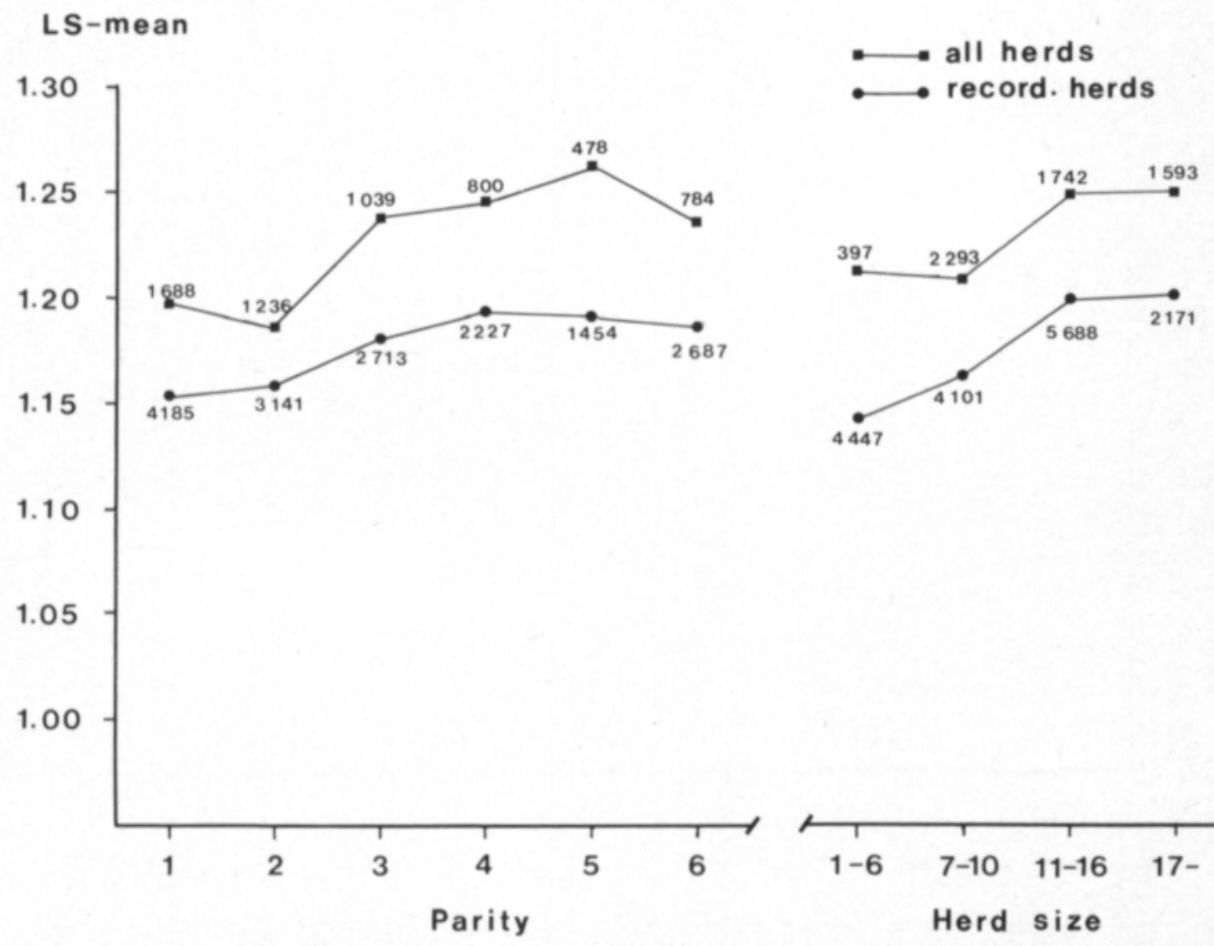

Figure 2. Least squares means for the effects of parity and herd size on ketosis incidence (no of observations given in graphs; $\mathrm{SE}: \mathrm{s}$ for all herds 0.005 to 0.029 , for record. herds 0.007 to 0.033 ). 
e.g. ERB \& MARTIN 1978 and SOLBU 1983) and the earlier Finnish study (KAUPPINEN 1984).

The effect of herd size is both in recorded and all herds clear, the incidence increases with increasing herd size. This is opposite to the findings of SOLBU (1983) and difficult to evaluate. Differences in production level (feeding practises), in herds of different sizes as well as differences in disease recording may influence the results. In our study the keto-test was carried out during only two months and included in most cases only one cow per farm in the smaller herd categories. In Norway the results are for one complete year and include data for whole herds.

Breed, feeding system and treatment

From fig. 3 is apparent that the breed differences are small, the ayrshire seems to have a somewhat higher incidence than the two other breeds.

The feeding system seems to influence the ketosis incidence, both in recorded and all herds the frequency increases with higher usage of commercial feed mixtures, although the effect is significant only in the total material. In SOLBUs (1983) study there was also a tendency of increasing incidence of ketosis with feeding increasing percentages of concentrates and grass silage.

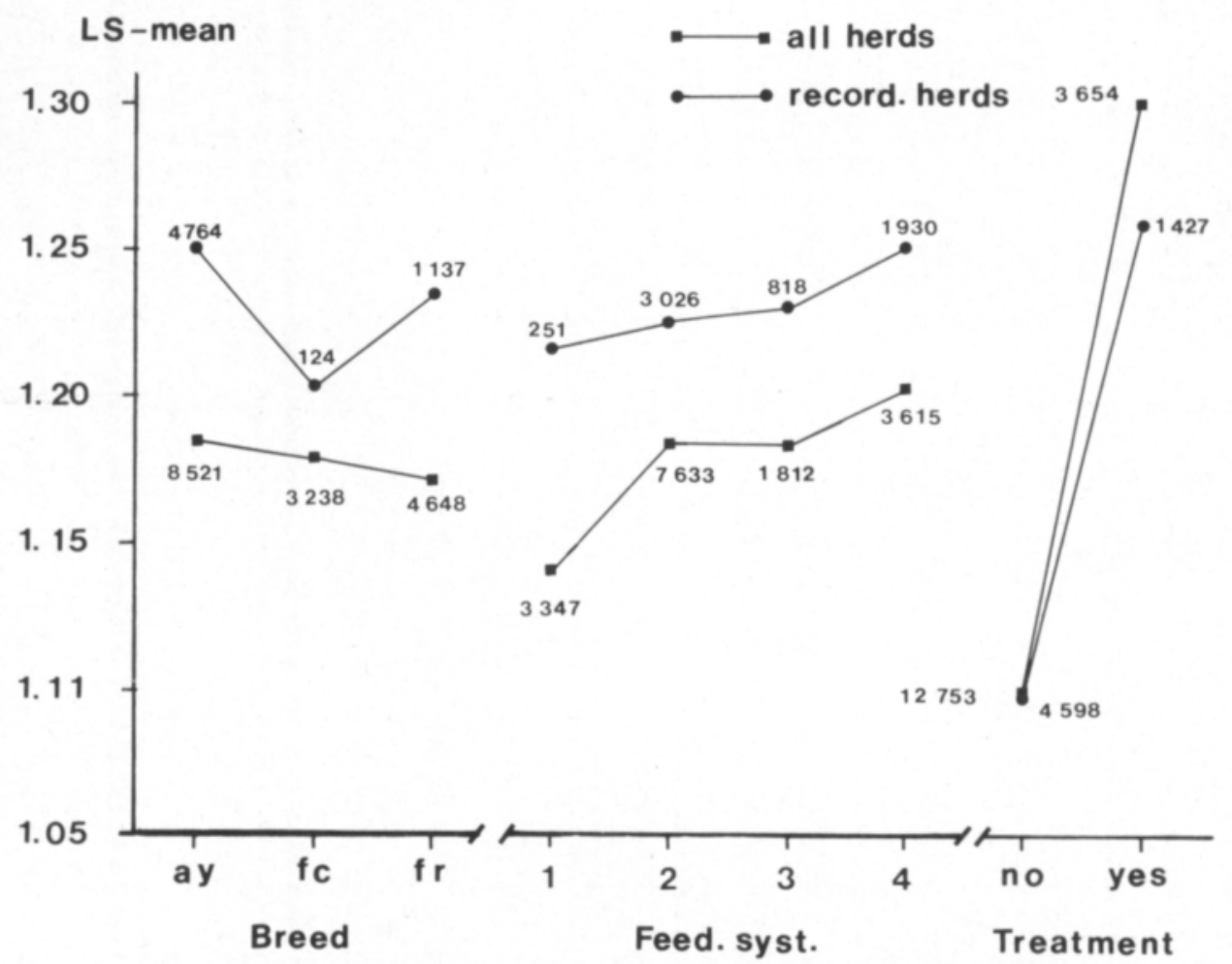

Figure 3. Least squares means for the effects of breed, feeding system and treatment on ketosis incidence ( $\mathrm{n}$ :o of observations given in graphs; SE:s for all herds 0.006 to 0.028 , for record. herds 0.008 to 0.059). 
Due to the rough classification of the feeding regimes in the present study, with no actual information on the amount and quality of the fodder fed to a particular cow, it is impossible to make firm conclusions about the noted tendency. It is, perhaps, possible that herds depending on commercial concentrate mixtures do not provide all of their cows with enough energy after calving and/or that they have somewhat lower quality of their home grown roughage than herds basing their feeding on own silage and hay. According to the study by PEHRSON \& WALLIN (1966) feeding of low quality silage increases the risk for ketosis.

The clear difference between the cows treated for ketosis and those not treated indicates two things (see also table 1). Firstly, that the treatment apparently has been justified. Secondly, that one treatment apparently has not been sufficient as the keto test still shows the presence of ketone bodies in treated cows.

Even if the reliability of the ketotest is influenced by the interpretation of the colour changes, the conditions (e.g. the humidity of the barn) of testing, the variation between individual cows and other factors, the present results indicate that it may be a useful indicator under field conditions. As the days from tratment to ketotesting was not known it is impossible to evaluate the latter's reliability in more detail.

\section{Milk yield and days from calving}

Fig. 4 shows the effects of daily milk yield and days from calving on the incidence of ketosis of recorded cows. Cows milking less than $25 \mathrm{~kg}$ have clearly higher incidences than those milking more. The literature is conflicting in this respect, some workers, e.g. EKESBO (1966) have found no connection between milk yield and ketosis, others e.g. PEHRSON (1966) and SOLBU (1983) have shown increasing incidences with increasing yields.

It should also be pointed out that it is very hard to separate cause and effect in this connection. Perhaps here it would be more logical to say that cows suffering from ketosis yield less than healthy ones.

One difference between our and the Norwegian study is that we used the recorded daily milk yield closest to the sampling event whereas Solbu used the maximum daily yield. The latter may be more sensitive to the occurrence of ketosis than the former. Even if parity was included in the model it is possible that the higher incidence for low producers partly is caused by the large number of first calvers in this group.

From the literature (see e.g. BAIRD et al. 1974) it is well known that ketosis occurs particularly in connection with parturition. This is confirmed in the present study, cows sampled earlier than 60 days after calving have significantly higher incidence than those sampled later. The same was noted by KAUPPINEN (1984). The peculiar rise in incidence for the cows inseminated after 261 days is probably due to missing calving dates. These cows have in fact calved more recently and therefore have a higher incidence. 


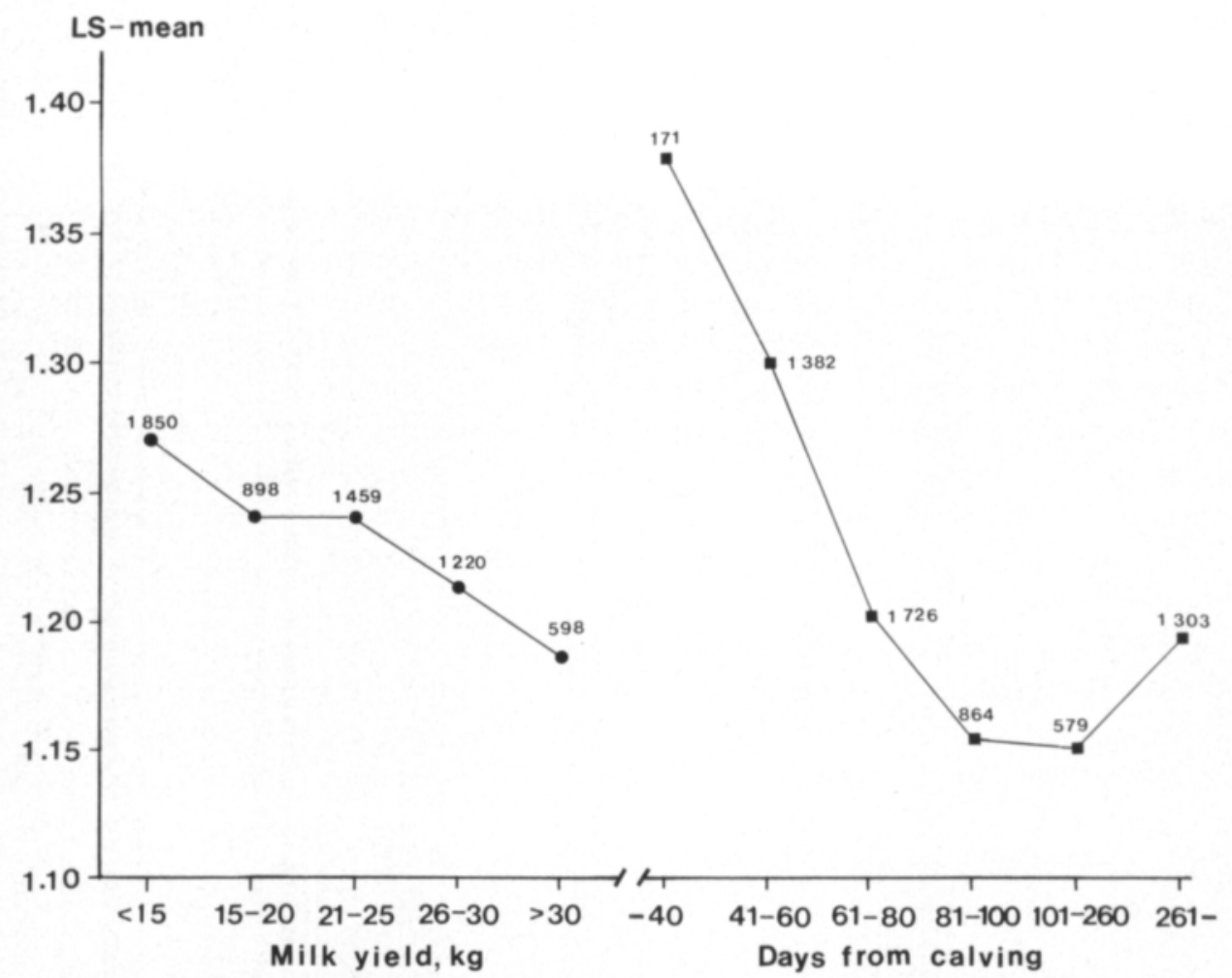

Figure 4. Least squares means for the effect of daily milk yield and days from calving on the incidence of ketosis in recorded herds (n:o of observations given in graphs; SE:s 0.008 to 0.057 ).

\section{Heritability}

The heritabilities for ketosis incidence were $0.18 \pm 2.02 \%$ (all cows) and $0.48 \pm 3.55 \%$ (recorded cows) and thus not significantly different from zero. This is in agreement with the literature (see e.g. SOLBU 1978).

NR-rate

On an average the NR-rate was only $60.5 \%$ and significantly higher in non-recorded than in recorded herds. The complete models accounted for 2 $\%$ (all herds) and $22 \%$ (recorded herds) of the variation in NR-rate as judged by the $\mathrm{R}^{2}$-values. The large difference between recorded and other herds is due to the inclusion of days after calving and milk yield in the model for the former category.

Table 2 outlines the effects of the above and some other fixed factors on the NR-rate. In accordance with the results for ketosis incidence, cows with higher daily milk production have better fertility results. Inseminating the cow later than 60 days after calving, naturally, gives significantly better NRrates.

Both for recorded and all cows there is a tendency for better fertility 
results with increasing proportion of home grown fodder, although the differences are statistically significant only in the latter category.

The most interesting finding is the clear negative influence of the ketosis incidence on the NR-rate both in recorded and nonrecorded herds. This underlines the need for prophylactic measures.

\section{Conclusions}

From the present study two conclusions appear justified:

1) Registration and utilisation of individual factors associated with the herd and/or with the cow are not at present of noticeable help in combating ketosis.

Table 2. Least squares means for the effects of some fixed factors significantly affecting non-return rates $(1$ = not returned., 2 = returned $)$ of cows in recorded $(\mathrm{R})$ and all herds $(\mathrm{A})$.

\begin{tabular}{|c|c|c|c|c|c|c|}
\hline \multirow{2}{*}{ Factor } & \multicolumn{2}{|c|}{$\mathrm{N}$} & \multicolumn{4}{|c|}{ LS-mean } \\
\hline & A & $\mathrm{R}$ & A & & $\mathrm{R}$ & \\
\hline$\mu$ & 16406 & 6025 & $1.409=$ & 0.048 & $1.454=$ & 0.045 \\
\hline \multicolumn{7}{|c|}{ Feeding system } \\
\hline 1 & 3347 & 251 & 1.432 & & 1.426 & \\
\hline 2 & 7633 & 3026 & 1.479 & & 1.460 & \\
\hline 3 & 1812 & 818 & 1.497 & & 1.489 & \\
\hline 4 & 3615 & 1930 & 1.486 & $F=5.1^{4 * 4}$ & 1.471 & $=1.5^{\mathrm{nt}}$ \\
\hline
\end{tabular}

Daily milk yield, $\mathrm{kg}$

\begin{tabular}{l|r|ll}
-15 & 1850 & 1.687 & \\
$15-20$ & 898 & 1.426 & \\
$21-25$ & 1459 & 1.386 & \\
$26-30$ & 1220 & 1.400 & \\
$31-$ & 598 & $1.409 \quad \mathrm{~F}=114.5^{\text {\%月H }}$
\end{tabular}

\begin{tabular}{|c|c|c|c|c|c|c|}
\hline \multicolumn{7}{|l|}{$\begin{array}{l}\text { Days from } \\
\text { calving }\end{array}$} \\
\hline-40 & & 171 & & & 1.587 & \\
\hline $41-60$ & & 1382 & & & 1.573 & \\
\hline $61-80$ & & 1726 & & & 1.515 & \\
\hline $81-100$ & & 864 & & & 1.484 & \\
\hline $101-260$ & & 579 & & & 1.389 & \\
\hline $261-$ & & 1303 & | & & 1.219 & $\mathrm{~F}=88.8^{\text {th+4 }}$ \\
\hline \multicolumn{7}{|l|}{ Ketosis score } \\
\hline 1 & 13906 & 5240 & 1.377 & & 1.412 & \\
\hline 2 & 2225 & 696 & 1.468 & & 1.447 & \\
\hline 3 & 275 & 89 & 1.577 & $\mathrm{~F}=32.0^{\mathrm{w}} \mathrm{m}$ & 1.525 & $\mathrm{~F}=4.2^{4}$ \\
\hline | not available & $\begin{array}{r}\text { ns } \\
* \\
* * *\end{array}$ & $\begin{array}{l}\text { not significant } \\
=0.05 \\
=0.001\end{array}$ & & 0.006 to 0.0 & & 0.009 to 0.028 \\
\hline
\end{tabular}


Therefore better measures of the herd environment (especially the quality of the feeds, and continuous registration of disease incidences and veterinary treatments should be encouraged. As SOLBU (1983) has shown, the herd as such accounts for some $12 \%$ of the variation in ketosis incidence.

2) The ketosis incidence can with satisfactory accuracy be registered by use of simple keto test reagents and is strongly negatively correlated with the NR-rate. Thus it would seem economically justified to try developing prophylactice (feeding) measures and to test for ketosis incidence as close to parturition as possible.

\section{References}

ANON. 1980. Veterinary Service. Official Statistics of Finland. XXXIV: 50.

BAIRD, G. D., HEITZMAN, R. I., HIBBIT, K. G. \& HUNTER, G. D. 1974. Bovine ketosis: A review with recommendations for control and treatment. Part I. Brit. vet. J. 130: 214-220.

EKESBO, I. 1966. Disease incidence in tied and loose-housed dairy cattle. Acta Agr. Scand. Suppl. 15: $1-74$.

ERB, H. N. \& MARTIN, S. W. 1978. Age, breed and seasonal patterns in the occurrence of ten dairy cow diseases; a case control study. Can. J. Comp. Med. 42: 1-9.

KAUPPINEN, K. 1984. Incidence of bovine ketosis in Finland in relation to lactation year and time of parturition. Acta Vet. Scand. (in press).

PEHRSON, B. 1966. Studies on ketosis in dairy cows. Acta Vet. Scand. 7, suppl. 15: 1-59.

— \& WALLIN, O. 1966. Sambandet mellan dålig ensilagekvalitet och acetonemi. Sv. Vetr. tidn. 18: 151-153.

S.A.S. 1979. Users Guide. Statistical Analysis System. P.O. Box 1006, Raleigh, North Carolina 27605, USA.

SOLBU, H. 1978. Breeding for disease resistance, with special emphasis on a practical method of collecting data. $29^{\text {th }}$ Ann. Meet. EAAP., Stockholm, Sweden, June $5^{\text {th }}-8^{\text {th }}, 8$ pp.

- 1983. Disease recording in Norwegian dairy cattle. I. Disease incidence and non-genetic effects on mastitis, ketosis and milk fever. Z. Tierzüchtg. Züchtgs.biol. 100: 139-157.

Ms received December 14, 1983 


\title{
Lypsykarjan ketoosiin vaikuttavista tekijöistä ja ketoosin esiinty- misen ja uusintatuloksen välisestä yhteydestä
}

\author{
U. B. Lindström ${ }^{1)}$, Marcus von Bonsdorff(2) and Jouko Syväjärvi ${ }^{3)}$ \\ 1) Helsingin Yliopisto, Kotieläinten jalostustieteen laitos, 00710 Helsinki 71 \\ 2) Itä- ja Keski-Suomen Keinosiemennysyhdistys, 76620 Pyhitty \\ 3) Suomen Kotieläinjalostusybdistys, PL 40, 01301 Vantaa 30
}

Itä- ja Keski-Suomen Ksy:n alueelta kerätty 16406 lehmää (6 025 tarkkailussa) käsittävä aineisto analysoitiin pienimmän neliösumman menetelmällä. Seminologi määritti ketoosin esiintymisen maidosta ensimmäisen poikimisenjälkeisen siemennyksen yhteydessä käyttäen kaupallista ketotestireagenssia. Ketoosia oli keskimäärin $11.5 \%$ : Ila lehmistä. Sen esiintyminen lisääntyi 4.-5. poikimiseen asti ja sitä oli selvästi enemmän suuremmissa karjoissa. Rotujen välillä ei ollut eroja ketoosin esiintymisessä. Kotovaraista rehua käyttävissä karjoissa oli ketoosia jonkun verran vähemmän kuin kaupallisia rehuja käyttävissä. Ketoosia sairastavilla lehmillä maidontuotanto oli alempi kuin muilla. Heti poikimisen jälkeen todettiin selvästi enemmän ketoosia kuin myöhemmin testatuilla lehmillä.

Täydelliset tilastolliset mallit selittivät vain $5 \%$ (kaikki karjat) ja $9 \%$ (tarkkailukarjat) ketoosin kokonaisvaihtelusta viitaten karjaympäristöä paremmin kuvaavien tekijöitten selvittämistarpeeseen.

Ketoosin esiintymisen periytyvyysasteet eivät poikenneet nollasta.

Ketoosia sairastavilla lehmillä oli selvästi heikompi tiinehtyvyys kuin terveillä korostaen ennalta ehkäisevien toimenpiteitten merkitystä. 